\title{
Design of solar huts
}

\author{
Xinyu Ling,Jinjuan Chen,Zhuoshou Pang
}

\author{
Department of Industrial Engineering, Tianjin University of Architecture, Tianjin, China
}

\begin{abstract}
This problem is a solar hut photovoltaic cell in the attached and overhead two installation methods, the type of photovoltaic cells and array mode and inverter type optimization design issues. In question 1, since the photovoltaic cells are attached to the roof and exterior surfaces, the direction and angle of the battery are uniquely determined by the direction and angle of the attached surface. The problem is translated to optimize the installation of a certain type on a single surface area (array) of photovoltaic cells, so that the total amount of solar photovoltaic power generation as much as possible, and the unit power generation costs as small as possible, which is a multi-objective optimization problem. The problem can be discussed in the ideal environment in a single surface area of the battery installation optimization program, and then the actual environment of the multi-surface optimization. In the solution to Problem 1, the unit on the south of the roof of the battery at the moment to accept the solar energy formula is generated. The definition of and is the moment of direct radiation intensity, for the moment the sun and the south of the roof of the plane where the angle, for the level of horizontal radiation intensity, for the south of the roof and the horizontal angle, the planefor the plane, the center of the heart, the vertical upward direction is the axis of the positive coordinate system, obtained with the sun height angle, the sun azimuth , red angle, angle and the sun when the relationship is generated. The conclusion is only installed in the small roof surface type of battery C11, and the rest of the surface is not installed. 35 years of electricity generation is 77126 degrees, the economic benefits of 16,488 yuan, the recovery period of 21.3 years. In question 2, because the photovoltaic cells in the roof and the external wall surface can be installed overhead, the panel orientation and tilt will affect the efficiency of photovoltaic cells. Therefore, in the optimization scheme of Problem 1, the orientation and inclination of the panel on each surface are further adjusted to calculate the optimum orientation and inclination of the panel on each surface. The problem can be in the ideal weather environment to establish the sun running and the battery board efficiency model, and then the measured environment test. The optimal orientation of the panel is southward, and the optimal angle with the ground plane is 39.89 degrees. The conclusion is only installed in the small roof surface type of battery C11, and the rest of the surface is not installed. 35 years of generating capacity of 82165.2 degrees, the economic benefits of 18,998 yuan, the recovery period of 13 years. In question 3, by the optimization of the above two issues, in the building to meet the requirements of the hut under the design of the various aspects of the cabin and battery installation, and further optimize the total power generation of the hut, economic benefits. The whole model solver is run in MATLAB7.0.
\end{abstract}

Key words:photovoltaic cell module inverter rated power

\section{Problem restatement}

In the design of solar huts, the need to build the outer surface of the building (roof and external walls) laying photovoltaic cells, photovoltaic modules produced by the DC power through the inverter into $220 \mathrm{~V}$ AC power for home use, and the remaining power into the grid. The price of each type of photovoltaic cell is very different, and the actual power generation efficiency or power generation per peak tile is affected by many factors such as solar radiation intensity, light incident angle, environment, geographical distance of the building, the regional climate and weather conditions, installation sites and methods and so on. Therefore, in the design of solar huts, it is important to study the optimal laying of photovoltaic cells on the outer surface of the hut.

Annex 1-7 provides relevant information. Please refer to the data provided in the annex to the following three issues, respectively, to give the outer surface of the cottage photovoltaic cell laying program, so that the whole year the total solar photovoltaic power generation as much as possible, and the unit power generation costs as small as possible, calculate the total amount of electricity generated in the 35year life period of the photovoltaic cells, the economic benefits (the current civil electricity price is 0.5 yuan $/ \mathrm{kWh}$ ) and the investment recovery period.

In the solution of each problem, are required to be equipped with illustrations, given the outer surface of the cabin battery packs to lay out the array graphics and component connection (string, parallel) diagram, but also to give the battery pack packet array capacity and optional reverse variable list of specifications.

In the same surface with two or more types of photovoltaic cell components, the same type of battery panels can be connected in series, and different types of panels cannot be connected in series. On different surfaces, even the same type of battery cannot be string, parallel connection. Attention should be paid to the combination of packet connection and inverter.

Question 1: According to the meteorological data of Datong City, Shanxi Province, only part of the outer surface of the hut (see Annex 2) is laid out by considering the installation method and the PV module is selected. According to the number and capacity of the battery pack, with the corresponding inverter capacity and quantity.

Question 2: The orientation and inclination of the panel will affect the efficiency of the photovoltaic cell. Please select the aerial type to install the photovoltaic cell and reconsider the problem.

Question 3: According to the requirements of the cottage construction given in Annex 7, please re-design a hut for Datong City, ask to draw the outline of the hut and optimize the laying of photovoltaic cells on the outer surface of the designed hut, giving laying and grouping, optional inverter, calculate the corresponding results.

\section{Problem analysis}

The problem is that a solar cottage photovoltaic cell in the two installation methods, the type of photovoltaic cells and array mode and inverter type optimization design issues.

In question 1, since the photovoltaic cells are attached to the roof and exterior surfaces, the direction and angle of the battery are uniquely determined by the direction and angle of the attached surface. The problem is translated to optimize the installation of a certain type on a single surface area (Array) of photovoltaic cells, so that the total amount of solar photovoltaic power generation as much as possible, and the unit power generation costs as small as possible, which is a multi-objective optimization problem. The problem can be discussed 
in the ideal environment in a single surface area of the battery installation optimization program, and then the actual environment of the multi-surface optimization.

In question 2, because the photovoltaic cells in the roof and the external wall surface can be installed overhead, the panel orientation and tilt will affect the efficiency of photovoltaic cells. Therefore, in the optimization scheme of Problem 1, the orientation and inclination of the panel on each surface are further adjusted to calculate the optimum orientation and inclination of the panel on each surface. The problem can be in the ideal weather environment to establish the sun running and the battery board efficiency model, and then the measured environment test.

In question 3, by the optimization of the above two issues, in the building to meet the requirements of the hut under the design of the various aspects of the cabin and battery installation, and further optimize the total power generation of the hut, economic benefits.

\section{Symbol description}

Solar elevation angle

Sun azimuth

Angle

Red angle

Datong latitude is

The direct direction of the sunlight and the normal angle of the panel

The azimuth of the panel

The height of the panel

Roof area

\section{Model assumptions}

3.1 Model assumptions

(1) Do not consider the weather changes, natural disasters and other factors, do not consider the human disturbance factors.

(2) Assume that the energy generated by the solar cottage can be effectively output.

(3) Do not consider the installation of the battery spacing and overhead equipment, wiring, labor hours and other installation costs and costs.

\section{Mdel of the establishment and solution}

Model one

In the ideal environment, that is, regardless of weather changes, natural disasters and human disturbance and other factors, the establishment of a sun in a year when running, fixed to the tilt and tilt of the panel, the panel received the sum of solar energy of the calculation model.

1, Assuming that the radiation intensity of the sun in the model is fixed, it is assumed that the rays from the sun are parallel and do not take into account the reflection of light;

2 , Set the size of the panel (regardless of the thickness);

3 , To the diagonal center of the panel as the origin, the sun azimuth and the sun height angle for the polar coordinates of the two directions, the sun height angle is the sun relative to the horizon of the height angle, which is the sun as the geometric center of the disk and the angle of the ideal horizon. The sun azimuth is the angle of the sun in the azimuth, that is, the angle measured clockwise from the north along the horizon. Create a spatial polar coordinate system as shown below

As can be seen from Annex 6, the solar elevation angle is approximated by the following formula:
The sun azimuth angle can also be used to calculate the approximation by the following two formulas,

for the sun's azimuth, for the sun's height angle, for the time angle, for the then sun's declination, for the local geographical latitude (Datong's latitude is ).

The normal direction of the panel is set in the coordinate system as, the direction of the sun as is that the light has the wave-particle duality, and the sunlight is regarded as the light quantum state, regardless of the fluctuation factor.

Theorem 1: The efficiency of solar panels to accept solar energy is proportional to the projected area of the panel in the direction of sunlight.

Let the angle between the direct direction of the sunlight and the normal direction of the panel be

Among them

By the projective area formula

The calculation of the model system in 35 years.

In the ideal state, do not consider the cost of the inverter, the efficiency of each battery and the economic results of the calculation of the following table (matlab code see annex), the results from the ideal income from large to small row.

Roof surface battery efficiency

Battery Type The Ideal Benefits (Yuan) After 35 Year-Old Battery Cost (Yuan)The Ideal Income (Yuan)

$\begin{array}{lllll}\text { B5 } & 13252.66 & 3500.00 & 9752.66 \\ \text { B2 } & 13578.98 & 4000.00 & 9578.98 \\ \text { A2 } & 13786.10 & 4842.50 & 8943.60 \\ \text { B6 } & 12605.78 & 3687.50 & 8918.28 \\ \text { A6 } & 12518.51 & 4395.50 & 8123.01 \\ \text { B1 } & 11328.86 & 3312.50 & 8016.36 & \\ \text { B7 } & 10686.69 & 3125.00 & 7561.69 \\ \text { A4 } & 11550.17 & 4023.00 & 7527.17 & \\ \text { B3 } & 10041.12 & 2625.00 & 7416.12 \\ \text { B4 } & 10291.13 & 3000.00 & 7291.13 \\ \text { A3 } & 10203.65 & 2980.00 & 7223.65 \\ \text { A5 } & 10469.24 & 3650.50 & 6818.74 \\ \text { A1 } & 9188.75 & 3203.50 & 5985.25 & \\ \text { C11 } & 4275.18 & 480.00 & 3795.18 & \\ \text { C1 } & 4272.27 & 480.00 & 3792.27 & \\ \text { C3 } & 4271.80 & 480.00 & 3791.80 & \\ \text { C2 } & 3843.96 & 432.00 & 3411.96 & \\ \text { C10 } & 2476.87 & 278.40 & 2198.47 & \\ \text { C9 } & 2137.57 & 240.00 & 1897.57 & \\ \text { C8 } & 512.60 & 57.60 & 455.00 & \\ \text { C7 } & 510.91 & 57.60 & 453.31 & \\ \text { C6 } & 341.53 & 38.40 & 303.13 & \\ \text { C5 } & 171.75 & 19.20 & 152.55 & \\ \text { C4 } & 170.74 & 19.20 & 151.54 & \\ & & & & \end{array}$

East to surface battery efficiency

Battery Type The Ideal Benefits (Yuan) After 35 Year-Old Battery Cost (Yuan)The Ideal Income (Yuan)

$\begin{array}{llll}\text { B5 } & 8564.814864 & 3500 & 5064.81486 \\ \text { B2 } & 8775.707524 & 4000 & 4775.70752 \\ \text { B6 } & 8146.757568 & 3687.5 & 4459.25757 \\ \text { A2 } & 8909.565173 & 4842.5 & 4067.06517 \\ \text { B1 } & 7321.520719 & 3312.5 & 4009.02072 \\ \text { B3 } & 6489.292243 & 2625 & 3864.29224\end{array}$




\begin{tabular}{llll}
\hline B7 & 6906.505489 & 3125 & 3781.50549 \\
A6 & 8090.356356 & 4395.5 & 3694.85636 \\
B4 & 6650.86171 & 3000 & 3650.86171 \\
A3 & 6594.330906 & 2980 & 3614.33091 \\
A4 & 7464.545537 & 4023 & 3441.54554 \\
A5 & 6765.970411 & 3650.5 & 3115.47041 \\
A1 & 5938.424196 & 3203.5 & 2734.9242 \\
C11 & 2762.924438 & 480 & 2282.92444 \\
C1 & 2761.04761 & 480 & 2281.04761 \\
C3 & 2760.743764 & 480 & 2280.74376 \\
C2 & 2484.244003 & 432 & 2052.244 \\
C10 & 1600.730664 & 278.4 & 1322.33066 \\
C9 & 1381.447717 & 240 & 1141.44772 \\
C8 & 331.2778436 & 57.6 & 273.677844 \\
C7 & 330.1854624 & 57.6 & 272.585462 \\
C6 & 220.7218037 & 38.4 & 182.321804 \\
C5 & 110.9979424 & 19.2 & 91.7979424 \\
C4 & 110.3461929 & 19.2 & 91.1461929
\end{tabular}

South to surface battery efficiency

Battery Type The Ideal Benefits (Yuan) After 35 Year-Old Battery Cost (Yuan)The Ideal Income (Yuan)

$\begin{array}{llll}\text { B5 } & 8682.28805 & 3500 & 5182.28805\end{array}$

$\begin{array}{llll}\text { B2 } & 8896.073269 & 4000 & 4896.07327\end{array}$

$\begin{array}{llll}\text { B6 } & 8258.496769 & 3687.5 & 4570.99677\end{array}$

$\begin{array}{llll}\text { A2 } & 9031.766882 & 4842.5 & 4189.26688\end{array}$

$\begin{array}{llll}\text { B1 } & 7421.941146 & 3312.5 & 4109.44115\end{array}$

B3 $\quad 6578.298001 \quad 2625 \quad 3953.298$

$\begin{array}{llll}\text { B7 } & 7001.233655 & 3125 & 3876.23366\end{array}$

$\begin{array}{llll}\text { A6 } & 8201.32197 & 4395.5 & 3805.82197\end{array}$

$\begin{array}{llll}\text { B4 } & 6742.083521 & 3000 & 3742.08352\end{array}$

$\begin{array}{llll}\text { A3 } & 6684.777352 & 2980 & 3704.77735\end{array}$

A4 $7566.927663 \quad 4023 \quad 3543.92766$

$\begin{array}{llll}\text { A5 } & 6858.771028 & 3650.5 & 3208.27103\end{array}$

$\begin{array}{llll}\text { A1 } & 6019.874364 & 3203.5 & 2816.37436\end{array}$

$\begin{array}{lll}\text { C11 } 2800.820124 & 480 & 2320.82012\end{array}$

$\begin{array}{llll}\text { C1 } & 2798.917554 & 480 & 2318.91755\end{array}$

$\begin{array}{llll}\text { C3 } & 2798.60954 & 480 & 2318.60954\end{array}$

$\begin{array}{llll}\text { C2 } & 2518.317368 & 432 & 2086.31737\end{array}$

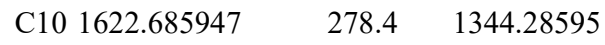

$\begin{array}{llll}\text { C9 } & 1400.395362 & 240 & 1160.39536\end{array}$

$\begin{array}{llll}\text { C8 } & 335.8215803 & 57.6 & 278.22158\end{array}$

$\begin{array}{llll}\text { C7 } & 334.7142162 & 57.6 & 277.114216\end{array}$

$\begin{array}{llll}\text { C6 } & 223.7491772 & 38.4 & 185.349177\end{array}$

$\begin{array}{llll}\text { C5 } & 112.5203666 & 19.2 & 93.3203666\end{array}$

$\begin{array}{llll}\text { C4 } & 111.8596779 & 19.2 \quad 92.6596779\end{array}$

West to surface battery efficiency

Battery Type The Ideal Benefits (Yuan) After 35 Year-Old Battery Cost (Yuan)The Ideal Income (Yuan)

$\begin{array}{llll}\text { B5 } & 8682.28805 & 3500 & 5182.28805\end{array}$

$\begin{array}{llll}\text { B2 } & 8896.073269 & 4000 & 4896.07327\end{array}$

$\begin{array}{llll}\text { B6 } & 8258.496769 & 3687.5 & 4570.99677\end{array}$

$\begin{array}{lllll}\text { A2 } & 9031.766882 & 4842.5 & 4189.26688\end{array}$

$\begin{array}{llll}\text { B1 } & 7421.941146 & 3312.5 & 4109.44115\end{array}$

$\begin{array}{llll}\text { B3 } & 6578.298001 & 2625 & 3953.298\end{array}$

$\begin{array}{llll}\text { B7 } & 7001.233655 & 3125 & 3876.23366\end{array}$

$\begin{array}{llll}\text { A6 } & 8201.32197 & 4395.5 & 3805.82197\end{array}$

$\begin{array}{llll}\text { B4 } & 6742.083521 & 3000 & 3742.08352\end{array}$

$\begin{array}{llll}\text { A3 } & 6684.777352 & 2980 & 3704.77735\end{array}$

A4 $7566.927663 \quad 4023 \quad 3543.92766$

$\begin{array}{llll}\text { A5 } & 6858.771028 & 3650.5 & 3208.27103\end{array}$

$\begin{array}{llll}\text { A1 } & 6019.874364 & 3203.5 & 2816.37436 \\ \text { C11 } & 2800.820124 & 480 & 2320.82012 \\ \text { C1 } & 2798.917554 & 480 & 2318.91755 \\ \text { C3 } & 2798.60954 & 480 & 2318.60954 \\ \text { C2 } & 2518.317368 & 432 & 2086.31737 \\ \text { C10 } & 1622.685947 & 278.4 & 1344.28595 \\ \text { C9 } & 1400.395362 & 240 & 1160.39536 \\ \text { C8 } & 335.8215803 & 57.6 & 278.22158 \\ \text { C7 } & 334.7142162 & 57.6 & 277.114216 \\ \text { C6 } & 223.7491772 & 38.4 & 185.349177 \\ \text { C5 } & 112.5203666 & 19.2 & 93.3203666 \\ \text { C4 } & 111.8596779 & 19.2 & 92.6596779\end{array}$

North to surface battery efficiency

Battery Type The Ideal Benefits (Yuan) After 35 Year-Old Battery Cost (Yuan)The Ideal Income (Yuan)

B5 $8775.0923500 \quad 5275.092$

B2 $8991.1634000 \quad 4991.163$

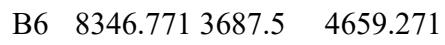

A2 $\quad 9128.3074842 .5 \quad 4285.807$

B1 $7501.2743312 .5 \quad 4188.774$

B3 $6648.6132625 \quad 4023.613$

$\begin{array}{lll}\text { B7 } & 7076.0693125 & 3951.069\end{array}$

A6 $8288.9854395 .5 \quad 3893.485$

B4 $6814.1493000 \quad 3814.149$

$\begin{array}{llll}\text { A3 } & 6756.23 & 2980 & 3776.23\end{array}$

A4 $7647.81 \quad 4023 \quad 3624.81$

A5 $\quad 6932.0843650 .5 \quad 3281.584$

A1 $6084.22 \quad 3203.5 \quad 2880.72$

C11 $2830.758480 \quad 2350.758$

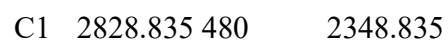

C3 $2828.524480 \quad 2348.524$

C2 $2545.235432 \quad 2113.235$

C10 1640.031278.4 1361.631

C9 $\quad 1415.364240 \quad 1175.364$

C8 $339.411257 .6 \quad 281.8112$

$\begin{array}{lll}\text { C7 } & 338.291957 .6 & 280.6919\end{array}$

$\begin{array}{lll}\text { C6 } & 226.140838 .4 & 187.7408\end{array}$

$\begin{array}{llll}\text { C5 } & 113.7231 & 19.2 \quad 94.5231\end{array}$

C4 $113.055319 .2 \quad 93.8553$

As can be seen from the above table, the efficiency of the battery type is constant in each surface. It is best B5, the worst is C4.

Datong measured the environment within 35 years of revenue calculation

The following with Datong year measured data to calculate the surface of the various types of battery efficiency, regardless of the cost of the inverter

Roof surface battery efficiency

Battery Type The Ideal Benefits (Yuan) After 35 Year-Old Battery Cost (Yuan)The Ideal Income (Yuan)

$\begin{array}{llll}\text { C11 } & 838.3295751 & 480 & 358.329575 \\ \text { C1 } & 837.7601057 & 480 & 357.760106 \\ \text { C3 } & 837.6679125 & 480 & 357.667913 \\ \text { C2 } & 753.7720507 & 432 & 321.772051 \\ \text { C10 } & 485.6954606 & 278.4 & 207.295461 \\ \text { C9 } & 419.1603874 & 240 & 179.160387 \\ \text { C8 } & 100.5166881 & 57.6 & 42.9166881 \\ \text { C7 } & 100.1852365 & 57.6 & 42.5852365 \\ \text { C6 } & 66.97165269 & 38.4 & 28.5716527 \\ \text { C5 } & 33.67911789 & 19.2 & 14.4791179 \\ \text { C4 } & 33.48136335 & 19.2 & 14.2813634\end{array}$




$\begin{array}{llll}\text { B3 } & 1968.988198 & 2625 & -656.0118 \\ \text { B5 } & 2598.745556 & 3500 & -901.2544 \\ \text { A3 } & 2000.859144 & 2980 & -979.1408 \\ \text { B4 } & 2018.011783 & 3000 & -981.9882 \\ \text { B7 } & 2095.5795 & 3125 & -1029.420 \\ \text { B1 } & 2221.503878 & 3312.5 & -1090.996 \\ \text { B6 } & 2471.898151 & 3687.5 & -1215.601 \\ \text { B2 } & 2662.734839 & 4000 & -1337.2652 \\ \text { A1 } & 1801.843208 & 3203.5 & -1401.6568 \\ \text { A5 } & 2052.938192 & 3650.5 & -1597.5618 \\ \text { A4 } & 2264.900626 & 4023 & -1758.099 \\ \text { A6 } & 2454.784834 & 4395.5 & -1940.715 \\ \text { A2 } & 2703.350075 & 4842.5 & -2139.1499\end{array}$

$\begin{array}{llll}\text { A1 } & 1088.149699 & 3203.5 & -2115.3503 \\ \text { B6 } & 1492.802047 & 3687.5 & -2194.698 \\ \text { B2 } & 1608.050079 & 4000 & -2391.9499 \\ \text { A5 } & 1239.788271 & 3650.5 & -2410.7117 \\ \text { A4 } & 1367.794336 & 4023 & -2655.2057 \\ \text { A6 } & 1482.467157 & 4395.5 & -2913.0328 \\ \text { A2 } & 1632.577994 & 4842.5 & -3209.922\end{array}$

West to surface battery efficiency

Battery Type 35 Years of The Ideal Benefits (Yuan) Battery Cost (Yuan) The Ideal Income (Yuan)

$\begin{array}{llll}\text { C11 } & 487.527654 & 480 & 7.527654 \\ \text { C1 } & 487.196481 & 480 & 7.196481 \\ \text { C3 } & 487.1428664 & 480 & 7.1428664 \\ \text { C2 } & 438.3535192 & 432 & 6.3535192 \\ \text { C10 } & 282.4545089 & 278.4 & 4.0545089 \\ \text { C9 } & 243.7612681 & 240 & 3.7612681 \\ \text { C8 } & 58.45513098 & 57.6 & 0.85513098 \\ \text { C7 } & 58.2623765 & 57.6 & 0.6623765 \\ \text { C6 } & 38.94713212 & 38.4 & 0.54713212 \\ \text { C5 } & 19.58597408 & 19.2 & 0.38597408 \\ \text { C4 } & 19.47097062 & 19.2 & 0.27097062 \\ \text { B3 } & 1145.058251 & 2625 & -1479.9417 \\ \text { A3 } & 1163.592689 & 2980 & -1816.4073 \\ \text { B4 } & 1173.567746 & 3000 & -1826.4323 \\ \text { B7 } & 1218.676983 & 3125 & -1906.323 \\ \text { B5 } & 1511.291456 & 3500 & -1988.7085 \\ \text { B1 } & 1291.907868 & 3312.5 & -2020.5921 \\ \text { A1 } & 1047.855662 & 3203.5 & -2155.6443 \\ \text { B6 } & 1437.523788 & 3687.5 & -2249.9762 \\ \text { B2 } & 1548.504202 & 4000 & -2451.4958 \\ \text { A5 } & 1193.879078 & 3650.5 & -2456.6209 \\ \text { A4 } & 1317.145096 & 4023 & -2705.8549 \\ \text { A6 } & 1427.571598 & 4395.5 & -2967.9284 \\ \text { A2 } & 1572.123851 & 4842.5 & -3270.3761\end{array}$

East to surface battery efficiency

Battery Type The Ideal Benefits (Yuan) After 35 Year-Old Battery Cost (Yuan)The Ideal Income (Yuan)

$\begin{array}{llll}\text { C11 } & 618.771236 & 480 & 138.771236 \\ \text { C1 } & 618.3509105 & 480 & 138.350911 \\ \text { C3 } & 618.2828627 & 480 & 138.282863 \\ \text { C2 } & 556.3593094 & 432 & 124.359309 \\ \text { C10 } & 358.4919218 & 278.4 & 80.0919218 \\ \text { C9 } & 309.3823702 & 240 & 69.3823702 \\ \text { C8 } & 74.19138863 & 57.6 & 16.5913886 \\ \text { C7 } & 73.9467442 & 57.6 & 16.3467442 \\ \text { C6 } & 49.43179096 & 38.4 & 11.031791 \\ \text { C5 } & 24.85856401 & 19.2 & 5.65856401 \\ \text { C4 } & 24.71260134 & 19.2 & 5.51260134 \\ \text { B3 } & 1453.310603 & 2625 & -1171.6894 \\ \text { A3 } & 1476.834556 & 2980 & -1503.1654 \\ \text { B4 } & 1489.494922 & 3000 & -1510.5051 \\ \text { B7 } & 1546.74767 & 3125 & -1578.2523 \\ \text { B5 } & 1918.134643 & 3500 & -1581.8654 \\ \text { B1 } & 1639.69248 & 3312.5 & -1672.8075 \\ \text { B6 } & 1824.508546 & 3687.5 & -1862.9915 \\ \text { A1 } & 1329.940851 & 3203.5 & -1873.5591 \\ \text { B2 } & 1965.365146 & 4000 & -2034.6349 \\ \text { A5 } & 1515.274112 & 3650.5 & -2135.2259 \\ \text { A4 } & 1671.723629 & 4023 & -2351.2764 \\ \text { A6 } & 1811.877203 & 4395.5 & -2583.6228 \\ \text { A2 } & 1995.34326 & 4842.5 & -2847.1567\end{array}$

South to surface battery efficiency

Battery Type The Ideal Benefits (Yuan) After 35 Year-Old Battery Cost (Yuan)The Ideal Income (Yuan)

$\begin{array}{llll}\text { C11 } & 506.274947 & 480 & 26.274947 \\ \text { C1 } & 505.9310392 & 480 & 25.9310392 \\ \text { C3 } & 505.8753629 & 480 & 25.8753629 \\ \text { C2 } & 455.2098797 & 432 & 23.2098797 \\ \text { C10 } & 293.3159594 & 278.4 & 14.9159594 \\ \text { C9 } & 253.1348162 & 240 & 13.1348162 \\ \text { C8 } & 60.70295315 & 57.6 & 3.10295315 \\ \text { C7 } & 60.50278653 & 57.6 & 2.90278653 \\ \text { C6 } & 40.44479752 & 38.4 & 2.04479752 \\ \text { C5 } & 20.3391293 & 19.2 & 1.1391293 \\ \text { C4 } & 20.21970352 & 19.2 & 1.01970352 \\ \text { B3 } & 1189.090097 & 2625 & -1435.9099 \\ \text { A3 } & 1208.337255 & 2980 & -1771.6627 \\ \text { B4 } & 1218.695891 & 3000 & -1781.3041 \\ \text { B7 } & 1265.539749 & 3125 & -1859.4603 \\ \text { B5 } & 1569.406362 & 3500 & -1930.5936 \\ \text { B1 } & 1341.58664 & 3312.5 & -1970.9134\end{array}$

North to surface battery efficiency

Battery Type 35 Years of The Ideal Benefits (Yuan) Battery Cost (Yuan) The Ideal Income (Yuan)

C11 $563.6804480 \quad 83.6804$

C1 $563.2975480 \quad 83.2975$

C3 $563.2355480 \quad 83.2355$

C2 $506.8252432 \quad 74.8252$

C10 $326.5744278 .4 \quad 48.1744$

$\begin{array}{lll}\text { C9 } & 281.8372240 \quad 41.8372\end{array}$

C8 $\quad 67.5859357 .6 \quad 9.98593$

$\begin{array}{lll}\text { C7 } & 67.3630757 .6 & 9.76307\end{array}$

C6 $45.0307538 .4 \quad 6.63075$

C5 $22.6453419 .2 \quad 3.44534$

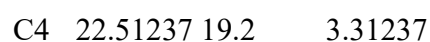

B3 $1323.9192625 \quad-1301.081$

A3 $1345.3482980 \quad-1634.652$

B4 $1356.8813000 \quad-1643.119$

B7 $1409.0373125 \quad-1715.963$

B5 $1747.3583500 \quad-1752.642$

B1 $1493.7063312 .5 \quad-1818.794$

A1 $1211.5333203 .5 \quad-1991.967$

B6 $1662.0683687 .5 \quad-2025.432$

B2 $1790.3834000 \quad-2209.617$

A5 $1380.3653650 .5 \quad-2270.135$

A4 $1522.8864023 \quad-2500.114$

A6 $\quad 1650.5614395 .5 \quad-2744.939$ 


A2 $1817.6934842 .5 \quad-3024.807$

Calculated from the actual data, the battery type is better income is $\mathrm{C} 11, \mathrm{C} 1, \mathrm{C} 3, \mathrm{C} 2$. Install the battery on the roof surface, the other surface due to the smaller income of each panel, taking into account the higher cost of the inverter, east, south, west and north of the surface is not the installation of the battery.

4.1 Problem (1): According to the meteorological data of Datong City, Shanxi Province, only the attached installation method is selected, the photovoltaic cell module is selected, the part of the outer surface of the hut is laid, and according to the number and capacity of the battery pack, The capacity and quantity of the inverter.

Since the photovoltaic cells are attached to the surface of the roof and exterior walls, the direction and angle of the battery are uniquely determined by the direction and angle of the attached surface. The problem is to optimize the installation of a certain type (array) of photovoltaic battery, so that the total amount of solar photovoltaic power generation as much as possible, and the unit power generation costs as small as possible, which is a multi-objective optimization problem. The problem can be discussed in the ideal environment in a single surface area of the battery installation optimization program, and then the actual environment of the multi-surface optimization.

Consider the viable combination of photovoltaic cells and inverters in the ideal environment (ie, regardless of the influence factors such as climate meteorological changes), where only one type of battery is connected to the same inverter, such as A1 -SN10 indicates that the inverter is SN10 and the battery is A1. Depending on the input voltage and input current of the inverter, the maximum combination of the arrays of the various types of batteries is shown in the following table (part of the data, see Annex *).

Array type

Battery Array (row * column) Array Power (w) Array Area

$\left(\mathrm{m}^{\wedge} 2\right) \quad$ Battery Price (yuan) Inverter Price (yuan)

Total Cost (yuan) Component area (m2) Watts / m2

$\begin{array}{rlllll}\text { C5- SN17 } & 6 * 24 & 14400 & 221.76 & 69120 & 43750 \\ 112870 & 221.76 & 649.35 & & & \end{array}$

C5-SN18 $6 * 24 \quad 14400 \quad 221.76 \quad 69120 \quad 54700$

$\begin{array}{lll}123820 & 221.76 & 649.35\end{array}$

C5-SN10 $1 * 123 \quad 12300 \quad 189.42 \quad 59040 \quad 63800$

$\begin{array}{lll}122840 & 189.42 & 649.35\end{array}$

$\begin{array}{llllll}\text { C5-SN7 } & 1 * 18 & 1800 & 27.72 & 8640 & 10200\end{array}$

$\begin{array}{llllll}18840 & 27.72 & 649.35 & & & \\ - \text { SN9 } & 1 * 61 & 6100 & 93.94 & 29280 & 35000\end{array}$

$\begin{array}{clllll}\text { C5-SN9 } & 1 * 61 & 6100 & 93.94 & 29280 & 35000 \\ 64280 & 93.94 & 649.35 & & & \end{array}$

C5-SN16 $2 * 29 \quad 5800 \quad 89.32 \quad 27840 \quad 35000$

$\begin{array}{lll}62840 & 89.32 & 649.35\end{array}$

C4-SN17 5*31 13950

$\begin{array}{lll}110710 & 23.87 & 584.42\end{array}$

C4-SN18 $5 * 31 \quad 13950$

$\begin{array}{lll}121660 & 23.87 & 584.42\end{array}$

C4-SN16 $1 * 38 \quad 3420 \quad 58.52 \quad 16416 \quad 35000$

$51416 \quad 58.52 \quad 584.42$

$\begin{array}{llllll}\text { B1-SN5 } & 1 * 8 & 2560 & 13.08 & 32000 & 10200\end{array}$

\begin{tabular}{llllll}
42200 & 13.08 & 195.70 & & & \\
\hline & $1 * 8$ & 2360 & 13.08 & 35164 & 10200
\end{tabular}

$\begin{array}{clllll}\text { A5- SN5 } & 1 * 8 & 2360 & 13.08 & 35164 & 10200 \\ 45364 & 13.08 & 180.41 & & & \end{array}$

$\begin{array}{llllll}\text { B4-SN5 } & 1 * 8 & 2240 & 13.02 & 28000 & 10200\end{array}$

$\begin{array}{llll}38200 & 13.02 & 172.11 & \end{array}$

$\begin{array}{llllll}\mathrm{A} 1-\mathrm{SN} 10 & 2 * 34 & 14620 & 86.81 & 70176 & 63800\end{array}$ $\begin{array}{lll}133976 & 86.81 \quad 168.41\end{array}$

$\begin{array}{llllll}\text { A } 1-\mathrm{SN} 17 & 14 * 6 & 18060 & 107.24 & 269094 & 43750\end{array}$

$\begin{array}{clllll}312844 & 107.24 & 168.41 & & & \\ \mathrm{~A} 1-\mathrm{SN} 18 & 14 * 6 & 18060 & 107.24 & 269094 & 54700 \\ 323794 & 107.24 & 168.41 & & & \\ \mathrm{~A} 1-\mathrm{SN} 6 & 1 * 19 & 4085 & 24.26 & 60866.5 & 15000 \\ 75866.5 & 24.26 & 168.41 & & & \\ \mathrm{~A} 1-\mathrm{SN} 5 & 1 * 12 & 2580 & 15.32 & 38442 & 10200 \\ 48642 & 15.32 & 168.41 & & & \\ \mathrm{~A} 1-\mathrm{SN} 4 & 1 * 8 & 1720 & 10.21 & 25628 & 6900 \\ \text { 32528 } & 10.21 & 168.41 & & & \\ \mathrm{~A} 1-\mathrm{SN} 8 & 2 * 8 & 3440 & 20.43 & 51256 & 15300 \\ 66556 & 20.43 & 168.41 & & & \\ \mathrm{~A} 1-\mathrm{SN} 7 & 2 * 5 & 2150 & 12.77 & 32035 & 10200 \\ 42235 & 12.77 & 168.41 & & & \end{array}$

According to the model and Datong measured data, it can be concluded that only the surface of the small roof installed on the battery type $\mathrm{C} 11$, the rest of the surface is not installed. 35 years of electricity generation is 77126 degrees, the economic benefits of 16,488 yuan, the recovery period of 21.3 years

4.2 Problem (2):

First, the best orientation of the panel and tilt calculation method:

Method 1 is the use of the problem 1 model, in a variety of orientation using matlab program search the best,

Battery Type 35 Years of The Ideal Benefits (Yuan) Battery

Cost (Yuan) The Ideal Income (Yuan)

$\begin{array}{llll}\text { C11 } & 893.0522566 & 480 & 413.052257 \\ \text { C1 } & 892.0380403 & 480 & 266.01902 \\ \text { C3 } & 891.8738455 & 480 & 265.936923 \\ \text { C2 } & 671.2282941 & 432 & 239.228294 \\ \text { C10 } & 432.5081239 & 278.4 & 154.108124 \\ \text { C9 } & 373.2591459 & 240 & 133.259146 \\ \text { C8 } & 89.50934835 & 57.6 & 31.9093483 \\ \text { C7 } & 89.21419329 & 57.6 & 31.6141933 \\ \text { C6 } & 59.63774878 & 38.4 & 21.2377488 \\ \text { C5 } & 29.99099904 & 19.2 & 10.790999 \\ \text { C4 } & 29.81490013 & 19.2 & 10.6149001 \\ \text { B3 } & 1753.369056 & 2625 & -871.63094 \\ \text { B5 } & 2314.163208 & 3500 & -1185.8368 \\ \text { A3 } & 1781.749892 & 2980 & -1198.2501 \\ \text { B4 } & 1797.024187 & 3000 & -1202.9758 \\ \text { B7 } & 1866.097651 & 3125 & -1258.9023 \\ \text { B1 } & 1978.232354 & 3312.5 & -1334.2676 \\ \text { B6 } & 2201.206555 & 3687.5 & -1486.2934 \\ \text { A1 } & 1604.527711 & 3203.5 & -1598.9723 \\ \text { B2 } & 2371.145179 & 4000 & -1628.8548 \\ \text { A5 } & 1828.125889 & 3650.5 & -1822.3741 \\ \text { A4 } & 2016.876829 & 4023 & -2006.1232 \\ \text { A6 } & 2185.967276 & 4395.5 & -2209.5327 \\ \text { A2 } & 2407.312738 & 4842.5 & -2435.1873\end{array}$

The installation method is described later, the conclusion is that the optimal orientation of the panel is southward, and the optimal angle with the ground plane is 39.89 degrees. Install the battery type on the surface of the small roof only $\mathrm{C} 11$, the rest of the surface is not installed. 35 years of generating capacity of 82165.2 degrees, the economic benefits of 18,998 yuan, the recovery period of 13 years. 
the roof surface and the other four sides are as follows:

Six, the results of the model analysis

In the solution to Problem 1, the unit on the south of the roof of the battery at the moment to accept the solar energy formula is

is the moment of direct radiation intensity, for the moment the sun and the south of the roof of the plane where the angle, for the level of horizontal radiation intensity, for the south of the roof and the horizontal angle, the plane for the plane, the center of the heart, The vertical upward direction is the axis of the positive coordinate system, obtained with the sun height angle, the sun azimuth, red angle, angle and the sun when the relationship is as follows

It is concluded that the battery type is only C11 on the surface of the small roof, and the rest surfaces are not installed. 35 years of electricity generation is 77126 degrees, the economic benefits of 16,488 yuan, the recovery period of 21.3 years.

In question 2, because the photovoltaic cells in the roof and the external wall surface can be installed overhead, the panel orientation and tilt will affect the efficiency of photovoltaic cells. Therefore, in the optimization scheme of Problem 1, the orientation and inclination of the panel on each surface are further adjusted to calculate the optimum orientation and inclination of the panel on each surface. The problem can be in the ideal weather environment to establish the sun running and the battery board efficiency model, and then the measured environment test. The optimal orientation of the panel is southward, and the optimal angle with the ground plane is 39.89 degrees.

It is concluded that the battery type is only $\mathrm{C} 11$ on the surface of the small roof, and the rest surfaces are not installed. 35 years of generating capacity of 82165.2 degrees, the economic benefits of 18,998 yuan, the recovery period of 13 years.

\section{REFERENCES}

[1] Shenzhen He Yueda Co., Ltd. The principle of solar panels, http: //www/pcol.cn (September 7, 2012)

[2] Yang Guiheng. Solar photovoltaic power generation system and its application, Beijing: Chemical Industry Press, 2011

[3] Chelsea, Zhang Chunming (translation). Solar photovoltaic power generation system, Beijing: Machinery Industry Press, 2011

[4] Shou Ji-lin. Mathematics and modeling - methods and cases. Xi'an: Xi'an

Jiaotong University Press, 1995

[5] Gong Jun. Mathematical modeling and experiment. Nanjing: Hohai University Press, 1998

[6] Jiang Qiyuan. Mathematical Model. Beijing: Higher Education Press, 1993

[7] Zhao Jing. Mathematical modeling and mathematical experiments, Beijing:

Higher Education Press, 2000

[8] Wang Xiangdong. Mathematics Experiment. Beijing: Higher Education

Press, 2004

[9] Chen Yihua. Mathematical Model. Chongqing: Chongqing University Press, 1995

[10] Zhao Kaihua, Zhong Xihua. Optics. Beijing: Peking University Press, 1982

[11] Bin Chuan Guihong, Zhang Hongmei, Cui Xiaohua. Solar photovoltaic cell and its application. Beijing: Science Press, 2008

[12] Zhang Xing, Cao Renxian. Solar photovoltaic grid-connected power generation and its inverter control. Beijing: Mechanical Industry Press, 2011 